Economic Impacts of Wyoming Landscape Conservation Initiative Conservation Projects in Wyoming

Open-File Report 2019-1135 



\section{Economic Impacts of Wyoming Landscape Conservation Initiative Conservation Projects in Wyoming}

By Christopher Huber, Matthew Flyr, and Catherine Cullinane Thomas

Open-File Report 2019-1135 


\section{U.S. Department of the Interior DAVID BERNHARDT, Secretary}

\section{U.S. Geological Survey James F. Reilly II, Director}

\section{U.S. Geological Survey, Reston, Virginia: 2020}

For more information on the USGS - the Federal source for science about the Earth, its natural and living resources, natural hazards, and the environment-visit https://www.usgs.gov or call 1-888-ASK-USGS.

For an overview of USGS information products, including maps, imagery, and publications, visit https://store.usgs.gov.

Any use of trade, firm, or product names is for descriptive purposes only and does not imply endorsement by the U.S. Government.

Although this information product, for the most part, is in the public domain, it also may contain copyrighted materials as noted in the text. Permission to reproduce copyrighted items must be secured from the copyright owner.

Suggested citation:

Huber, C., Flyr, M., and Cullinane Thomas, C., 2020, Economic impacts of Wyoming Landscape Conservation Initiative conservation projects in Wyoming: U.S. Geological Survey Open-File Report 2019-1135, 11 p., https://doi.org/10.3133/ofr20191135.

ISSN 0196-1497 (print) ISSN 2331-1258 (online) ISBN 978-1-4113-4342-9 


\section{Acknowledgments}

This research was supported by the U.S. Geological Survey Wyoming Landscape Conservation Initiative and the U.S. Geological Survey Ecosystems Mission Area. The authors would like to thank Patrick Anderson (U.S. Geological Survey) for supplying the necessary data for this analysis, and Justin Caudill (Wyoming Department of Agriculture) and Jennifer Dobb (Bureau of Land Management, Wyoming State Office) for providing critical reviews of this report. 


\section{Contents}

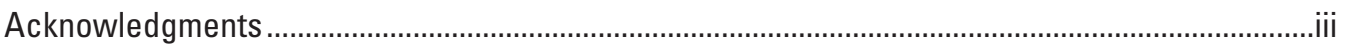

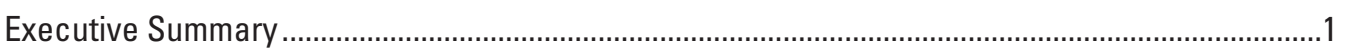

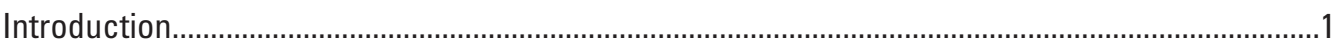

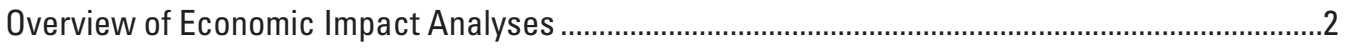

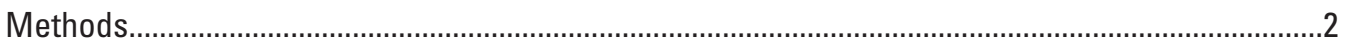

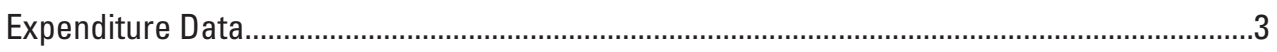

Economic Impacts of Restoration Activities and Material Expenditures.................................5

Economic Impacts of Conservation Easement Purchases.......................................................

Animal Unit Month Purchases and Land Donations ................................................................

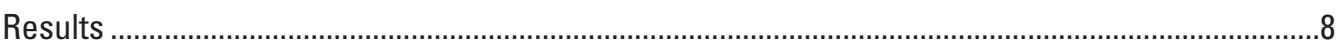

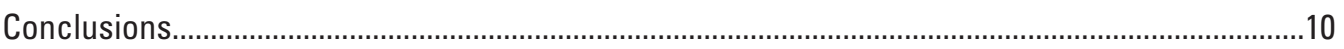

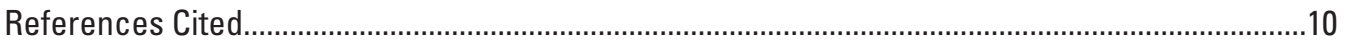

\section{Figures}

1. Total Wyoming Landscape Conservation Initiative expenditures by type from 2007 to 2018 (in 2018 dollars).

2. Number of job-years supported by Wyoming Landscape Conservation Initiative conservation project expenditures for the major job categories.

\section{Tables}

1. Wyoming Landscape Conservation Initiative expenditures by year (in 2018 dollars) for project treatments

2. North American Industry Classification System code and description, and best-fit IMPLAN sector number and description, by restoration activity

3. North American Industry Classification System code and description, and best-fit IMPLAN commodity code and description, for purchased materials.

4. Federal conservation easement expenditure profile based on Colorado landowners from 2009 to 2017.

5. Spending category, IMPLAN sector, and IMPLAN sector description for conservation easements

6. Economic impacts of Wyoming Landscape Conservation Initiative conservation project actions, material purchases, and conservation easement purchases.

7. Economic impacts of Wyoming Landscape Conservation Initiative conservation project expenditures by treatment type.

\section{Abbreviations}

AUM animal unit month

BLM Bureau of Land Management

NAICS North American Industry Classification System

USGS U.S. Geological Survey

WLCI Wyoming Landscape Conservation Initiative 


\title{
Economic Impacts of Wyoming Landscape Conservation Initiative Conservation Projects in Wyoming
}

\author{
By Christopher Huber, Matthew Flyr, and Catherine Cullinane Thomas
}

\section{Executive Summary}

This report estimates the economic impacts on the Wyoming economy from investments made by the Wyoming Landscape Conservation Initiative (WLCI) on conservation and restoration projects. The WLCI has been working in southwestern Wyoming since 2007 to coordinate science and management decisions among government and private entities that invest in conservation projects aimed at restoring and enhancing wildlife habitat. These investments support jobs and generate business activities within the Wyoming economy. WLCI conservation and restoration projects occur on both publicly managed and privately owned lands and are supported by leveraging funds from Federal bureaus, Wyoming State and local government agencies, and private contributions. During 2007-2018, the WLCI invested a total of more than $\$ 69,100,000$ (in 2018 dollars) on conservation projects within the State of Wyoming. These pooled funds have been used to purchase conservation easements and hire business contractors to complete restoration projects, with 98 percent of project funds awarded to Wyoming-based businesses. Including both direct and secondary effects, the U.S. Geological Survey estimates that local spending on these conservation and restoration projects during 2007-2018 supported an estimated 1,055 job-years (the number of annualized full- and part-time jobs generated or supported), more than $\$ 30,500,000$ in labor income, almost $\$ 40,900,000$ in value added, and almost $\$ 68,200,000$ in economic output within the Wyoming economy. These results demonstrate how investments in WLCI conservation projects support jobs, livelihoods, small businesses, and rural economies in Wyoming.

\section{Introduction}

The southwestern Wyoming landscape includes sagebrush, mountain shrub, aspen, riparian, and aquatic communities that provide habitat for deer, elk (Cervus elaphus), pronghorn (Antilocapra Americana), Greater Sage-Grouse (Centrocercus urophasianus), fish, and nongame species (Wyoming Landscape Conservation Initiative [WLCI], 2012). Like the rest of the State's economy, the regional economy's most prominent sectors are mineral and energy development, outdoor recreation and tourism, and agriculture; each of these sectors rely upon natural resources to be economically viable. The accelerated pace of energy development in the region since the early 2000s has led to increasing urban and exurban development in wildlife habitat areas (Assal and Montag, 2012; Zeigenfuss and others, 2019).

The WLCI partnership, which started in 2007 to facilitate balanced, scientifically based land-use decisions in southwestern Wyoming, includes partners at the Federal, State, and local levels of government (https:/www.wlci.gov). As a founding member of the WLCI, the U.S. Geological Survey (USGS) provides scientific information on aquatic and terrestrial habitats at the landscape scale (Zeigenfuss and others, 2019). The WLCI uses this scientific information in conjunction with local-partner knowledge to develop and implement conservation projects aimed at restoring and enhancing wildlife habitat with a clear focus on sagebrush, mountain shrub, aspen, riparian, and aquatic communities (WLCI, 2017).

The WLCI's conservation and restoration projects are implemented on both publicly managed and privately owned lands and are supported by leveraging funds from Federal bureaus, Wyoming State government agencies, and private contributions. Since 2007 , more than $\$ 69,100,000$ (in 2018 dollars) have been invested in WLCI conservation and restoration projects throughout southwestern Wyoming. These pooled funds have been used to purchase conservation easements and hire business contractors to complete restoration projects, thereby supporting jobs and business activities in the Wyoming economy. This report quantifies the economic impacts to Wyoming from WLCI conservation project expenditures made from 2007 through 2018.

This analysis builds off past USGS research on data requirements and methods to estimate the economic impacts of ecosystem restoration expenditures at the project level for the U.S. Department of the Interior's Bureau of Land Management (BLM) and Natural Resource Damage Assessment and Restoration program (Cullinane Thomas and others, 2016). Cullinane Thomas and others (2016) developed case studies of the economic impacts of restoration projects by surveying individual project managers to acquire 
detailed project-level expenditure data. Several case studies examined in the 2016 report are comparable to the WLCI conservation and restoration projects, including sagebrush enhancement projects for the BLM's Color Country District in Utah and BLM's Twin Falls District in Idaho. Other notable case studies estimated the economic impacts of instream habitat restoration in Colorado, post-wildfire restoration in Oregon, noxious and invasive weed treatments in Nevada, and hazardous fuels reduction projects in New Mexico and Nevada. USGS recently applied a modified survey instrument to estimate the economic impacts of National Park Service restoration projects (Cullinane Thomas and others, 2019) and wildfire risk reduction and source water protection projects in New Mexico and southern Colorado (Huber and others, in press). This current study on WLCI conservation projects differs with these past examples because of the wide variety of project types that have spanned over many years. Thus, the scope of this study represents a portfolio of project types compared to individual case studies examined in past USGS research.

\section{Overview of Economic Impact Analyses}

Economic impact analyses measure the economic activity supported by expenditures in an economy (Loomis, 2002; Cullinane Thomas and others, 2016). When money enters an economy, it is first spent directly on services, such as restoration construction. This initial expenditure is referred to as a "direct effect." Firms receiving the direct expenditure then spend money on inputs, such as concrete or riprap, to complete their work. Firms supplying these inputs must make their own round of purchases from other input suppliers to satisfy the increase in demand for their own inputs. These subsequent rounds of purchases are referred to as "indirect effects." The direct and indirect purchases generate jobs and income, and the employees reinject their income into the economy to purchase household goods and services such as housing, groceries, and child care. Spending by households is referred to as "induced effects." Together, indirect and induced effects form the secondary effects associated with the initial direct expenditure (Cullinane Thomas and others, 2016). Input-output models are often used to estimate direct and secondary economic impacts. These models utilize regional economic multipliers to detail how an initial round of spending "multiplies" as it travels throughout the complex web of the local economy.

\section{Methods}

Building off of past research, this study estimates the economic impacts of WLCI conservation projects by applying the IMPLAN input-output modeling software and data system to WLCI project expenditures using the IMPLAN Pro v3.1 2017 dataset (IMPLAN Group LLC, 2018). For economic impact modeling, project expenditures are summed by year and treatment category and matched to a North American Industry Classification System (NAICS) code and a best-fit IMPLAN sector (NAICS code information can be found at https://www.census.gov/eos/www/naics/). The local area in this study is defined as the state of Wyoming, reflecting the fact that most of the project expenditures were spent within the state (roughly 98 percent), and because WLCI coordinators expressed interest in understanding the economic impacts of WLCI project expenditures on the Wyoming economy. Defining the local area is necessary for an economic impact analysis because the regional economic multipliers in an input-output model only reflect the industries and input availability in the defined local economy. If a firm must purchase inputs from outside of the local region to satisfy a change in demand, the purchase is "leaked" from the model and creates no new economic activity inside of the local area. Generally, a narrow local area definition will generate smaller multipliers and economic impacts because fewer inputs are available locally (Huber and others, in press).

For this study of WLCI conservation projects, only project expenditures paid to Wyoming-based contractors and input suppliers are included in the economic impact analysis. Most expenditures are modeled as being paid directly to the producer or service provider. However, several material purchases were made from local wholesalers and some portion of landowner conservation easement income was spent in local retail sectors; in these situations, wholesale margins and retail margins, respectively, were applied. All economic impacts are shown in 2018 dollars. Four economic metrics were estimated:

1. Job-years. - The number of annualized full- and part-time jobs generated or supported by WLCI projects.

2. Labor income.-The employee compensation (wages/salaries and payroll benefits) and proprietor income resulting from the jobs supported by WLCI projects.

3. Value added.-The value of production of goods and services supported by WLCI projects, not including the cost of business-to-business purchases (intermediate purchases). Value added is an equivalent measure to gross regional product.

4. Economic output.-The total value of the production of goods and services supported by WLCI projects, equal to the total of all intermediate purchases plus sales to consumers (final demand). Value added is one component of economic output, and therefore summing value added and economic output would be double counting economic impacts. 


\section{Expenditure Data}

All annual WLCI expenditure data from 2007 to 2018 were tracked by year in a Microsoft Access database by WLCI coordinators. Tracked project data included funds allocated by the WLCI, BLM, and other Federal sources; State funding; local funding; funds received from other sources; and in-kind contributions. Other tracked data included each project's point of contact, a project description, project treatment type (for example, sagebrush thinning, prescribed burning, seeding), type of habitat (for example, aspen, sagebrush, riparian areas), and species benefiting from the treatment (for example, mule deer, elk, livestock).

Many projects were funded from more than one source (for example, BLM and the State). For each project, total annual cost is the sum of all reported Federal, State, and private funds, and funds from other sources. In-kind contributions are generally omitted from the total funding calculations; however, in-kind contributions are included (1) in cases where the database documented donated materials that would have otherwise been purchased, (2) when costs were shared for hired labor, and (3) when transportation of materials was donated.

The treatment type reported in the WLCI expenditure database is used to group project annual funding into the treatment categories that are used for economic impact modeling. However, for many projects, more than one treatment type was reported for the same year but the particular costs for the different treatment categories were not specified. For these cases, a review of the reported funding amount, the project description, and professional judgment were used to categorize project expenditures to the largest treatment category for the project. For example, a project was described as both preparing for a "prescribed burn" and "sagebrush thinning" for the same year. In this case, "sagebrush thinning" was selected as the overarching project treatment for the year because more acres were treated than were prepared for the prescribed burn. In cases where the type of treatment was not reported, the project description written by the project's point of contact was reviewed to judge the best-fit treatment category.

After adjusting for inflation, WLCI conservation project expenditures totaled \$69,116,433 (in 2018 dollars) from 2007 to 2018. Segmenting the total project expenditures by treatment category shows that more than one-half of total expenditures (\$36,824,449 after rounding up to the nearest dollar) were spent on restoration activities and less than one-half $(\$ 31,825,377)$ were used to purchase conservation easements (fig. 1). The remainder of the total is divided between material purchases $(\$ 192,139)$ and land donations and animal unit month (AUM) purchases $(\$ 274,468)$. AUM purchases provide financial compensation to permittees who willingly waive their allotment grazing permits to the public land managing agency so that the land can be rested and vegetation can be improved for wildlife.

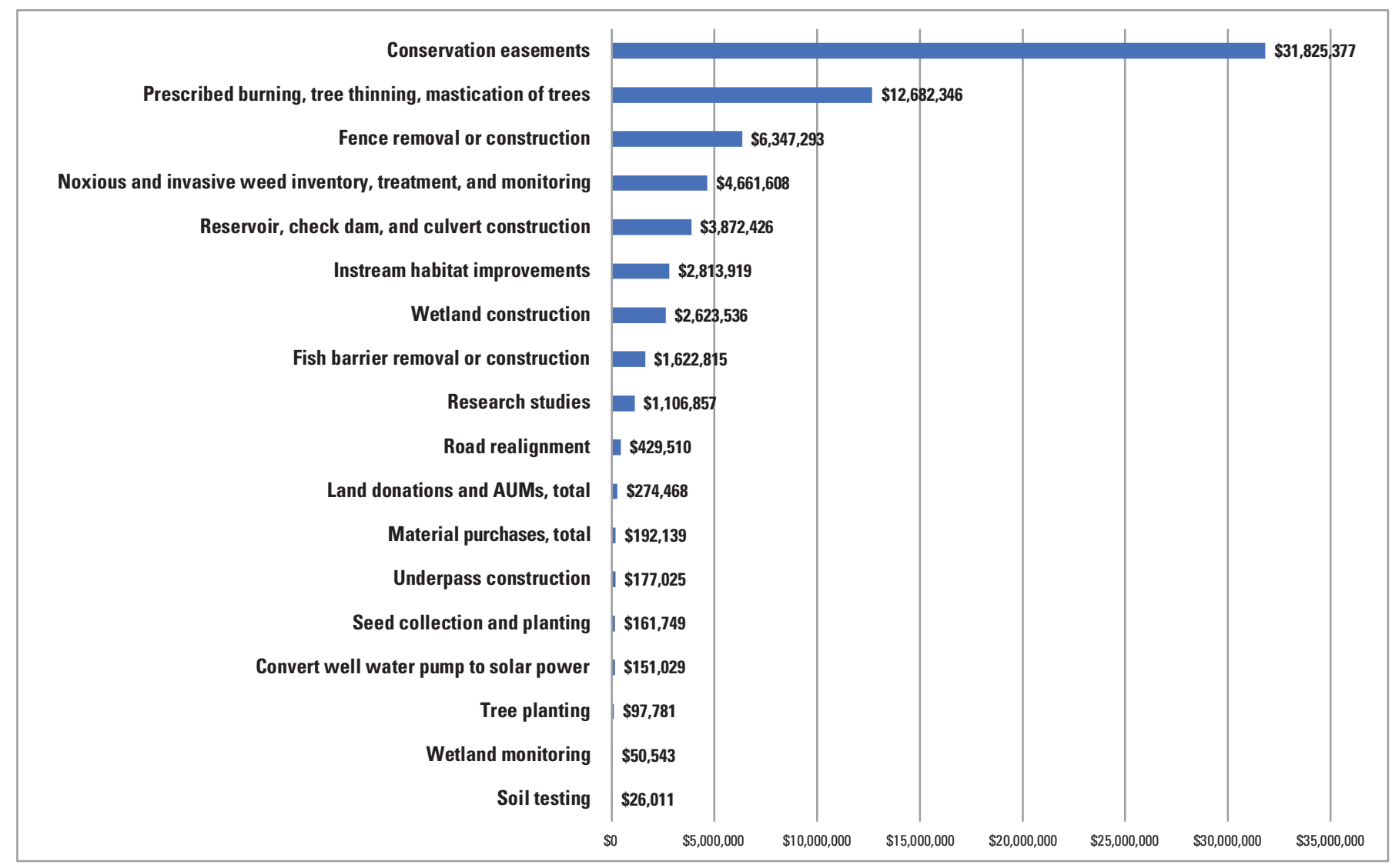

Figure 1. Total Wyoming Landscape Conservation Initiative expenditures by type from 2007 to 2018 (in 2018 dollars). (AUM, animal unit month) 
The project treatment type with the largest proportion of action expenditures, totaling $\$ 12,682,346$, is "Prescribed burning, tree thinning, and mastication of trees." This is followed by "Fence removal or construction" $(\$ 6,347,293)$; "Noxious and invasive weed inventory, treatment, and monitoring" $(\$ 4,661,608)$; and "Reservoir, check dam, and culvert construction" $(\$ 3,872,426)$. The total costs by treatment type are further segmented by year for modeling purposes and are summarized in table 1 .

Table 1. Wyoming Landscape Conservation Initiative expenditures by year (in 2018 dollars) for project treatments.

[Totals may not add because of rounding. AUM, animal unit month]

\begin{tabular}{|c|c|c|c|c|c|c|c|c|c|c|c|c|c|}
\hline $\begin{array}{l}\text { Project } \\
\text { treatment }\end{array}$ & \multicolumn{12}{|c|}{ Year } & Total \\
\hline $\begin{array}{l}\text { Convert well water } \\
\text { pump to solar } \\
\text { power }\end{array}$ & $\$ 0$ & $\$ 0$ & $\$ 0$ & $\$ 0$ & $\$ 0$ & $\$ 0$ & $\$ 0$ & $\$ 0$ & $\$ 0$ & $\$ 151,029$ & $\$ 0$ & $\$ 0$ & $\$ 151,029$ \\
\hline $\begin{array}{c}\text { Fence removal or } \\
\text { construction }\end{array}$ & $\$ 0$ & $\$ 1,390,013$ & $\$ 370,185$ & $\$ 1,244,562$ & $\$ 367,489$ & $\$ 288,049$ & $\$ 101,750$ & $\$ 1,061,657$ & $\$ 171,662$ & $\$ 341,667$ & $\$ 1,010,259$ & $\$ 0$ & $\$ 6,347,293$ \\
\hline $\begin{array}{l}\text { Instream habitat } \\
\text { improvements }\end{array}$ & $\$ 0$ & $\$ 248,574$ & $\$ 180,517$ & $\$ 226,034$ & $\$ 0$ & $\$ 200,140$ & $\$ 207,831$ & $\$ 54,589$ & $\$ 69,913$ & $\$ 726,124$ & $\$ 603,606$ & $\$ 296,591$ & $\$ 2,813,919$ \\
\hline $\begin{array}{l}\text { Noxious and invasive } \\
\text { weed inventory, } \\
\text { treatment, and } \\
\text { monitoring }\end{array}$ & $\$ 28,813$ & $\$ 33,479$ & $\$ 291,437$ & $\$ 151,563$ & $\$ 277,051$ & $\$ 370,691$ & $\$ 503,398$ & $\$ 685,448$ & $\$ 690,066$ & $\$ 728,399$ & $\$ 901,260$ & $\$ 0$ & $\$ 4,661,608$ \\
\hline Research studies & $\$ 0$ & $\$ 0$ & $\$ 68,589$ & $\$ 0$ & $\$ 251,944$ & $\$ 371,168$ & $\$ 280,031$ & $\$ 14,690$ & $\$ 2,002$ & $\$ 0$ & $\$ 118,433$ & $\$ 0$ & $\$ 1,106,857$ \\
\hline $\begin{array}{l}\text { Reservoir, check } \\
\text { dam, and culvert } \\
\text { construction }\end{array}$ & $\$ 0$ & $\$ 0$ & $\$ 239,771$ & $\$ 263,400$ & $\$ 101,302$ & $\$ 187,207$ & $\$ 74,382$ & $\$ 410,695$ & $\$ 673,218$ & $\$ 1,664,920$ & $\$ 257,532$ & $\$ 0$ & $\$ 3,872,426$ \\
\hline Road realignment & $\$ 0$ & $\$ 0$ & $\$ 0$ & $\$ 0$ & $\$ 51,077$ & $\$ 70,190$ & $\$ 152,076$ & $\$ 0$ & $\$ 0$ & $\$ 156,166$ & $\$ 0$ & $\$ 0$ & $\$ 429,510$ \\
\hline $\begin{array}{l}\text { Seed collection and } \\
\text { planting }\end{array}$ & $\$ 0$ & $\$ 0$ & $\$ 70,792$ & $\$ 0$ & $\$ 33,811$ & $\$ 57,145$ & $\$ 0$ & $\$ 0$ & $\$ 0$ & $\$ 0$ & $\$ 0$ & $\$ 0$ & $\$ 161,749$ \\
\hline Soil testing & $\$ 0$ & $\$ 0$ & $\$ 0$ & $\$ 0$ & $\$ 0$ & $\$ 10,260$ & $\$ 15,751$ & $\$ 0$ & $\$ 0$ & $\$ 0$ & $\$ 0$ & $\$ 0$ & $\$ 26,011$ \\
\hline Tree planting & $\$ 0$ & $\$ 0$ & $\$ 0$ & $\$ 0$ & $\$ 0$ & $\$ 0$ & $\$ 0$ & $\$ 0$ & $\$ 0$ & $\$ 40,410$ & $\$ 57,372$ & $\$ 0$ & $\$ 97,781$ \\
\hline $\begin{array}{r}\text { Land donations and } \\
\text { AUM purchases }\end{array}$ & $\$ 0$ & $\$ 261,315$ & $\$ 0$ & $\$ 0$ & $\$ 0$ & $\$ 0$ & $\$ 0$ & $\$ 13,153$ & $\$ 0$ & $\$ 0$ & $\$ 0$ & $\$ 0$ & $\$ 274,468$ \\
\hline Grand total ${ }^{1}$ & & & & & & & & & & & & & $\$ 69,116,433$ \\
\hline
\end{tabular}

\footnotetext{
${ }^{1}$ Nonlocal expenditures, land donations, and AUM purchases were subtracted from this amount and the remaining $\$ 67,770,377$ was used for the economic impact model.
} 


\section{Economic Impacts of Restoration Activities and Material Expenditures}

For economic impact modeling, treatment categories shown in table 1 are matched to a NAICS code and a best-fit IMPLAN sector (table 2). Similarly, material purchases (\$192,139 in total) are summed by project year and material, and then matched to a NAICS code and a best-fit IMPLAN commodity (table 3). (Note: Two categories not represented in tables 2 and 3 are "conservation easements" and "land donations and AUM purchases," which are discussed in the "Economic Impacts of Conservation Easement Purchases" and "Animal Unit Month Purchases and Land Donations" sections.)

Economic impact modeling results associated with material expenditures are treated as secondary economic impacts because the purchase of a material is a purchase down the supply chain from the initial construction/restoration investment that made the purchase possible. In this sense, the material purchase is a "ripple effect" and not the initial drop of water into the pool. (Note: all economic impacts from material purchases in the "Results" section are reported by the treatment that the material was used for, and not by material, allowing actions and material economic impacts to be summed together.)

Table 2. North American Industry Classification System (NAICS) code and description, and best-fit IMPLAN sector number and description (from IMPLAN Group, LLC, 2018), by restoration activity.

\begin{tabular}{|c|c|c|c|c|}
\hline $\begin{array}{l}\text { Restoration } \\
\text { activity }\end{array}$ & $\begin{array}{l}\text { NAICS } \\
\text { code }\end{array}$ & $\begin{array}{c}\text { NAICS } \\
\text { description }\end{array}$ & $\begin{array}{l}\text { Best-fit IMPLAN } \\
\text { sector }\end{array}$ & $\begin{array}{l}\text { IMPLAN sector } \\
\text { description }\end{array}$ \\
\hline Convert well water pump to solar power & 23 & $\begin{array}{c}\text { Maintenance and repair of reservoirs, pump } \\
\text { stations, and water pipeline construction }\end{array}$ & 62 & $\begin{array}{l}\text { Maintenance and repair con- } \\
\text { struction of nonresidential } \\
\text { structures }\end{array}$ \\
\hline Fence removal or construction & 23 & Fencing & 58 & $\begin{array}{l}\text { Construction of other new non- } \\
\text { residential structures }\end{array}$ \\
\hline Instream habitat improvements & 23 & Conservation and development construction & 58 & $\begin{array}{l}\text { Construction of other new non- } \\
\text { residential structures }\end{array}$ \\
\hline $\begin{array}{l}\text { Noxious and invasive weed inventory, } \\
\text { treatment, and monitoring }\end{array}$ & 115112 & Weed control services for crops & 19 & $\begin{array}{l}\text { Support activities for agriculture } \\
\text { and forestry }\end{array}$ \\
\hline $\begin{array}{l}\text { Reservoir, check dam, and culvert } \\
\text { construction }\end{array}$ & 23 & $\begin{array}{l}\text { Reservoirs, pump stations, and water } \\
\text { pipeline construction }\end{array}$ & 58 & $\begin{array}{l}\text { Construction of other new non- } \\
\text { residential structures }\end{array}$ \\
\hline Road realignment & 23 & Highways, streets, and related work & 56 & $\begin{array}{l}\text { Construction of new highways } \\
\text { and streets }\end{array}$ \\
\hline Seed collection and planting & 115310 & Forestry services & 19 & $\begin{array}{l}\text { Support activities for agriculture } \\
\text { and forestry }\end{array}$ \\
\hline Soil testing & 541690 & Geochemical consulting services & 455 & $\begin{array}{l}\text { Environmental and other techni- } \\
\text { cal consulting services }\end{array}$ \\
\hline Wetland monitoring & 541690 & Biological consulting services & 455 & $\begin{array}{l}\text { Environmental and other techni- } \\
\text { cal consulting services }\end{array}$ \\
\hline
\end{tabular}


Table 3. North American Industry Classification System (NAICS) code and description, and best-fit IMPLAN commodity code and description (from IMPLAN Group, LLC, 2018), for purchased materials.

\begin{tabular}{|c|c|c|c|c|}
\hline $\begin{array}{l}\text { Material } \\
\text { purchased }\end{array}$ & $\begin{array}{l}\text { NAICS } \\
\text { code }\end{array}$ & $\begin{array}{l}\text { NAICS } \\
\text { description }\end{array}$ & $\begin{array}{l}\text { Best-fit IMPLAN } \\
\text { commodity }\end{array}$ & IMPLAN commodity description \\
\hline Drill bit & 333120 & $\begin{array}{l}\text { Bits, rock drill, construction and surface } \\
\text { mining-type, manufacturing }\end{array}$ & 3264 & Construction machinery \\
\hline Herbicide & 325320 & Herbicides manufacturing & 3172 & $\begin{array}{l}\text { Pesticides and other agricultural } \\
\text { chemicals }\end{array}$ \\
\hline Rock & 21231 & Stone mining and quarrying & 3030 & Stone \\
\hline Piping & 331110 & $\begin{array}{l}\text { Fence posts, iron or steel, made in iron and } \\
\text { steel mills }\end{array}$ & 3217 & $\begin{array}{l}\text { Iron and steel and ferroalloy } \\
\text { products }\end{array}$ \\
\hline Riprap & 21231 & Stone mining and quarrying & 3030 & Stone \\
\hline
\end{tabular}

\section{Economic Impacts of Conservation Easement Purchases}

Conservation easement purchases make up a large portion of overall WLCI project expenditures (fig. 1, table 1). Under a conservation easement, a landowner maintains ownership of their property but transfers some of their ownership rights to a conservation entity; this leaves land in private ownership while providing a cost-effective conservation strategy that enables the conservation of large blocks of habitat. Conservation easement purchases inject new money into a local economy through payments to landowners. Information on how landowners spend these payments is needed to model economic impacts. For this analysis, economic impacts of WLCI conservation easement purchases are modeled following the method outlined in Seidl and others (2018), who estimated the economic impact of Federal conservation easements paid to Colorado landowners from 2009 to 2017. Seidl and others (2018) used survey results to develop a spending profile categorizing typical landowner spending of conservation easement payments; the spending profile is documented in table 4.

Table 4. Federal conservation easement expenditure profile based on Colorado landowners from 2009 to 2017 (modified from Seidl and others, 2018).

$[\%$, percent $]$

\begin{tabular}{lr}
\hline \multicolumn{1}{c}{ Spending category } & Portion \\
\hline Invested in agriculture & $15.11 \%$ \\
\hline Invested in nonagriculture & $1.10 \%$ \\
\hline Agricultural expansion & $13.22 \%$ \\
\hline Savings & $17.33 \%$ \\
\hline Family education & $0.21 \%$ \\
\hline Debt & $51.74 \%$ \\
Nonbusiness goods & $0.09 \%$ \\
\hline Other & $1.20 \%$ \\
\hline
\end{tabular}

Total WLCI easement payments are categorized, based on the Seidl and others (2018) spending profile, into corresponding sectors in an aggregated IMPLAN model; sectors are aggregated based on the scheme shown in table 5. Easement spending on debt and savings are leaked from the model because no new economic impacts are generated by these activities. 
Table 5. Spending category, IMPLAN sector, and IMPLAN sector description for conservation easements (modified from Seidl and others, 2018).

\begin{tabular}{|c|c|c|}
\hline $\begin{array}{l}\text { Spending } \\
\text { category }\end{array}$ & $\begin{array}{l}\text { IMPLAN } \\
\text { sector }\end{array}$ & $\begin{array}{l}\text { IMPLAN sector } \\
\text { description }\end{array}$ \\
\hline \multirow[t]{3}{*}{ Invested in agriculture } & 2 & Grain farming \\
\hline & 11 & Beef cattle ranching and farming, including feedlots and dual-purpose ranching and farming \\
\hline & 19 & Support activities for agriculture and forestry \\
\hline \multirow[t]{2}{*}{ Invested in nonagriculture } & 496 & Other amusement and recreation industries \\
\hline & 500 & Other accommodations \\
\hline Agricultural expansion & 440 & Real estate \\
\hline Savings & 433 & Monetary authorities and depository credit intermediation \\
\hline \multirow[t]{3}{*}{ Family education } & 472 & Elementary and secondary schools \\
\hline & 473 & Junior colleges, colleges, universities, and professional schools \\
\hline & 474 & Other educational services \\
\hline \multirow[t]{4}{*}{ Debt } & 433 & Monetary authorities and depository credit intermediation \\
\hline & 434 & Nondepository credit intermediation and related activities \\
\hline & 435 & Securities and commodity contracts intermediation \\
\hline & 436 & Other financial investment activities \\
\hline Nonbusiness goods & 396 & Retail—Motor vehicle and parts dealers \\
\hline \multirow[t]{6}{*}{ Other } & 397 & Retail—Furniture and home furnishings stores \\
\hline & 403 & Retail—Clothing and clothing accessories stores \\
\hline & 404 & Retail-Sporting goods, hobby, musical instrument and book stores \\
\hline & 405 & Retail—General merchandise stores \\
\hline & 406 & Retail-Miscellaneous store retailers \\
\hline & 407 & Retail-Nonstore retailers \\
\hline
\end{tabular}

\section{Animal Unit Month Purchases and Land Donations}

Land donations and AUM purchases account for a small portion of total WLCI conservation project expenditures ( $\$ 274,468$, less than 0.4 percent of total expenditures) and are excluded from the economic impact analysis. AUM purchases provide financial compensation to a willing permittee for waiving their allotment grazing permit back to the public land managing agency (for example, the Forest Service). The objective of AUM purchases is to remove livestock from the area so that the watershed and vegetation conditions will improve for fish and wildlife species. Although money does exchange hands, the net economic impact of this transfer is close to zero. 


\section{Results}

During the period 2007-2018, the WLCI spent more than $\$ 69,100,00$ on conservation projects within the State of Wyoming. Including direct and secondary effects, expenditures included in the IMPLAN model of more than $\$ 67,700,000$ (which excludes nonlocal expenditures, land donations, and AUM purchases) supported an estimated 1,055 job-years, more than $\$ 30,500,000$ in labor income, almost $\$ 40,900,000$ in value added, and almost $\$ 68,200,000$ in economic output in the Wyoming economy (table 6).

Table 6. Economic impacts of Wyoming Landscape Conservation Initiative conservation project actions, material purchases, and conservation easement purchases.

[Totals may not add because of rounding]

\begin{tabular}{lcccc}
\hline $\begin{array}{c}\text { Economic impact } \\
\text { type }\end{array}$ & Job-years & $\begin{array}{c}\text { Labor income } \\
\text { (thousands of 2018 dollars) }\end{array}$ & $\begin{array}{c}\text { Value added } \\
\text { (thousands of 2018 dollars) }\end{array}$ & $\begin{array}{c}\text { Economic output } \\
\text { (thousands of 2018 dollars) }\end{array}$ \\
\hline Direct effect & 900 & $\$ 24,293$ & $\$ 28,626$ & $\$ 45,480$ \\
Secondary effect & 155 & $\$ 6,213$ & $\$ 12,228$ & $\$ 22,690$ \\
Total effect & $\mathbf{1 , 0 5 5}$ & $\mathbf{\$ 3 0 , 5 0 6}$ & $\mathbf{\$ 4 0 , 8 5 4}$ & $\$ \mathbf{6 6 8 , 1 6 9}$ \\
\hline
\end{tabular}

The total number of job-years $(1,055)$ supported by WLCI conservation project expenditures can be segmented by treatment category (fig. 2). "Prescribed burning, tree thinning, mastication of trees" supported the highest number of job-years (524) followed by "Noxious and invasive weed inventory, treatment, and monitoring" (210 job-years), "conservation easements" (116 job-years), and "Fence removal or construction" (64 job-years).

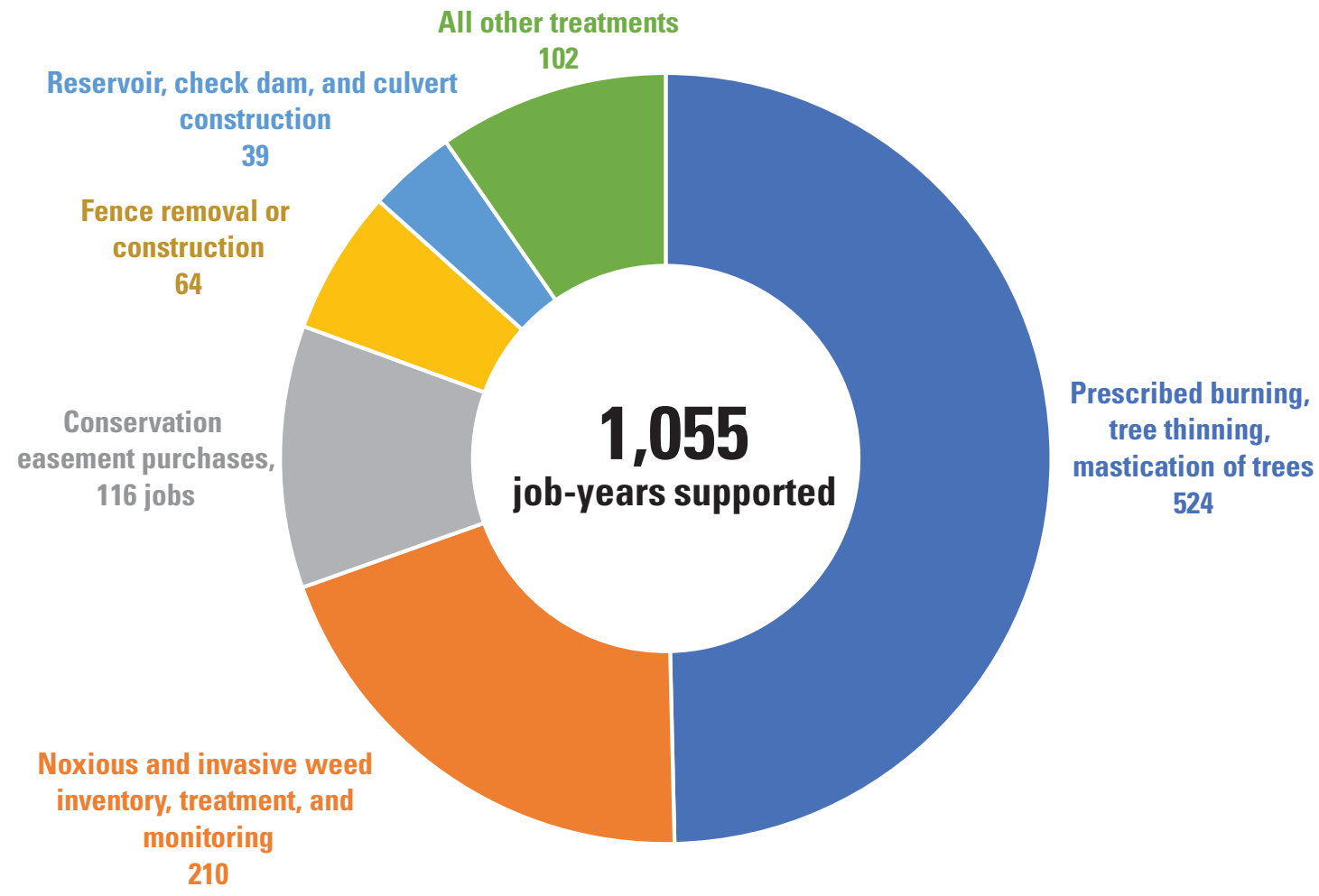

Figure 2. Number of job-years supported by Wyoming Landscape Conservation Initiative conservation project expenditures for the major job categories. 
In addition to job-years, results for the other economic impact measures (labor income, value added, and economic output) can be summarized by treatment type (table 7). Comparing across the treatment types for each economic impact measure reveals that, in addition to supporting the largest number of job-years, "Prescribed burning, tree thinning, mastication of trees" also generated the highest labor income $(\$ 12,839,000)$, valued added $(\$ 13,318,000)$, and economic output $(\$ 17,958,000)$.

Table 7. Economic impacts of Wyoming Landscape Conservation Initiative conservation project expenditures by treatment type.

[Totals may not add because of rounding]

\begin{tabular}{|c|c|c|c|c|}
\hline $\begin{array}{l}\text { Treatment } \\
\text { type }\end{array}$ & Job-years & $\begin{array}{l}\text { Labor income } \\
\text { (thousands of } 2018 \text { dollars) }\end{array}$ & $\begin{array}{c}\text { Value added } \\
\text { (thousands of } 2018 \text { dollars) }\end{array}$ & $\begin{array}{l}\text { Economic output } \\
\text { (thousands of } 2018 \text { dollars) }\end{array}$ \\
\hline $\begin{array}{l}\text { Convert well water pump to solar } \\
\text { power }\end{array}$ & 2 & $\$ 77$ & $\$ 114$ & $\$ 228$ \\
\hline Fence removal or construction & 64 & $\$ 3,342$ & $\$ 4,961$ & $\$ 9,294$ \\
\hline Fish barrier removal or construction & 16 & $\$ 856$ & $\$ 1,271$ & $\$ 2,377$ \\
\hline $\begin{array}{l}\text { Noxious and invasive weed inventory, } \\
\text { treatment, and monitoring }\end{array}$ & 210 & $\$ 5,157$ & $\$ 5,351$ & $\$ 7,216$ \\
\hline $\begin{array}{l}\text { Prescribed burning, tree thinning, } \\
\text { mastication of trees }\end{array}$ & 524 & $\$ 12,839$ & $\$ 13,318$ & $\$ 17,958$ \\
\hline Research studies & 11 & $\$ 587$ & $\$ 865$ & $\$ 1,844$ \\
\hline Seed collection and planting & 7 & $\$ 179$ & $\$ 186$ & $\$ 250$ \\
\hline Soil testing & 0 & $\$ 23$ & $\$ 26$ & $\$ 42$ \\
\hline Tree planting & 4 & $\$ 108$ & $\$ 112$ & $\$ 151$ \\
\hline Underpass construction & 2 & $\$ 86$ & $\$ 127$ & $\$ 277$ \\
\hline Wetland construction & 26 & $\$ 1,378$ & $\$ 2,044$ & $\$ 3,826$ \\
\hline Wetland monitoring & 1 & $\$ 45$ & $\$ 51$ & $\$ 81$ \\
\hline Conservation easement purchases & 116 & $\$ 2,095$ & $\$ 6,883$ & $\$ 14,161$ \\
\hline Total effect & 1,055 & $\$ 30,506$ & $\$ 40,854$ & $\$ 68,169$ \\
\hline
\end{tabular}

These results demonstrate how investments in landscape conservation projects support jobs and livelihoods within the local economy; however, these measures are only one component to the full economic, ecological, or socially relevant outcomes from WLCI projects. The economic impacts reported here represent immediate economic activity supported by WLCI conservation project expenditures. A more complete story from an enhanced landscape may include the long-term changes in productivity to livestock grazing and increased tourism activities (Cullinane Thomas and others, 2016). Beyond these economic impact measures exists a distinctly different outcome from an improved landscape that can be measured as the economic benefits (or values) supported by the landscape (Champ and others, 2017). These economic benefit measures are the welfare or enjoyment that individual people receive from, for example, outdoor recreation access for hunting (Loomis and Walsh, 1997; Rosenberger and others, 2017), improved water quality (Johnston and others, 2017), and preservation of wildlife (Richardson and Loomis, 2009). 


\section{Conclusions}

This report estimates the economic impacts on the Wyoming economy from investments made by the Wyoming Landscape Conservation Initiative (WLCI) on conservation and restoration projects from 2007 to 2018 to coordinate science and management decisions among government and private entities that invest in conservation projects aimed at restoring and enhancing wildlife habitat. These investments support jobs and generate business activities within the Wyoming economy. During 2007-2018, the WLCI invested a total of more than $\$ 69,100,000$ (in 2018 dollars) on conservation projects within the State of Wyoming. These funds have been used to purchase conservation easements and hire business contractors to complete restoration projects, with 98 percent of project funds awarded to Wyoming-based businesses. Including both direct and secondary effects, the U.S. Geological Survey estimates that local spending on these conservation and restoration projects during 2007-2018 supported an estimated 1,055 jobyears (the number of annualized full- and part-time jobs generated or supported), more than $\$ 30,500,000$ in labor income, almost $\$ 40,900,000$ in value added, and almost $\$ 68,200,000$ in economic output within the Wyoming economy. These results demonstrate how investments in WLCI conservation projects support jobs, livelihoods, small businesses, and rural economies in Wyoming.

\section{References Cited}

Assal, T.J., and Montag, J.M., 2012, A tale of two land uses in the American West—Rural residential growth and energy development: Journal of Maps, v. 8, no. 4, p. 327-333.

Champ, P.A., Boyle, K.J., and Brown, T.C., eds., 2017, A primer on nonmarket valuation $2^{\text {nd }}$ ed.: The Netherlands, Springer, 504 p.

Cullinane Thomas, C., Huber, C., Skrabis, K., and Sidon, J., 2016, Estimating the economic impacts of ecosystem restorationMethods and case studies: U.S. Geological Survey Open-File Report 2016-1016, 98 p., accessed November 18, 2019, at https://doi.org/10.3133/ofr20161016.

Cullinane Thomas C., Van Gilder, N., and VanMouwerik, M., 2019, Economic impacts of restoration in national parks: Fort Collins, Colo., National Park Service, Natural Resource Report NPS/NRSS/EQD/NRR—2019/1860, 18 p.

Huber, C., Cullinane Thomas, C., Meldrum, J.R., Meier, R., and Bassett, S., in press, Economic effects of wildfire risk reduction and source water protection projects in the Rio Grande River Basin in northern New Mexico and southern Colorado: U.S. Geological Survey Open-File Report 2019-1108, 8 p.

IMPLAN Group, LLC, 2018, IMPLAN 2017 National Data Set: Huntersville, N.C., accessed August 9, 2019, at http:// www.implan.com/.

Johnston, R.J., Besedin, E.Y., and Stapler, R., 2017, Enhanced geospatial validity for meta-analysis and environmental benefit transfer-An application to water quality improvements: Environmental and Resource Economics, v. 68, no. 2, p. 343-375.

Loomis, J.B., 2002, Integrated public lands management—Principles and applications to national forests, parks, wildlife refuges, and BLM lands: New York, Columbia University Press, 594 p.

Loomis, J.B., and Walsh, R.G., 1997, Recreation economic decisions-Comparing benefits and costs $2^{\text {nd }}$ ed.: State College, Pa., Venture Publishing Inc., 440 p.

Richardson, L., and Loomis, J., 2009, The total economic value of threatened, endangered and rare species-An updated metaanalysis: Ecological Economics, v. 68, no. 5, p. 1535-1548.

Rosenberger, R.S., White, E.M., Kline, J.D., and Cvitanovich, C., 2017, Recreation economic values for estimating outdoor recreation economic benefits from the National Forest System: Portland, Oreg., U.S. Department of Agriculture, Forest Service, Pacific Northwest Research Station, Gen. Tech. Rep. PNWGTR-957, 33 p.

Seidl, A., Swartzentruber, R., and Hill, R., 2018, Estimated economic impact of Federal Agricultural Conservation Easement Programs (ACEP) on Colorado, 2009-2017: Fort Collins, Colo., Colorado State University Department of Agricultural and Resource Economics, accessed July 3, 2019, at https://cowestlandtrust.org/wp-content/uploads/ csu307173-RuralLandResearch-bk-www-1.pdf.

Wyoming Landscape Conservation Initiative [WLCI], 2012, WLCI Fact Sheet: Wyoming Landscape Conservation Initiative, accessed July 7, 2019, at https://www.wlci.gov/sites/default/files/misc-files/Fact\%20Sheet\%20general\%20final.pdf. 
Wyoming Landscape Conservation Initiative [WLCI], 2017, Annual Report: Wyoming Landscape Conservation Initiative, accessed July 7, 2019, at https://www.wlci.gov/sites/default/files/misc-files/2017_WLCI_Annual_Report.pdf.

Zeigenfuss, L.C., Aikens, E., Aldridge, C.L., Anderson, P.J., Assal, T.J., Bowen, Z.H., Chalfoun, A.D., Chong, G.W., Eddy-Miller, C.A., Germaine, S.S., Graves, T., Homer, C.G., Huber, C.C., Johnston, A., Kauffman, M.J., Manier, D.J., McShane, R.R., Miller, K.A., Monroe, A.P., Ortega, A., Walters, A.W., and Wyckoff, T.B., 2019, U.S. Geological Survey science for the Wyoming Landscape Conservation Initiative-2017 annual report: U.S. Geological Survey Open-File Report 2018-1188, 57 p., accessed November 18, 2019, at https://doi.org/10.3133/ofr20181188.

Publishing support provided by the Science Publishing Network, Denver Publishing Service Center

For more information concerning the research in this report, contact the Center Director, USGS Fort Collins Science Center

2150 Centre Ave., Bldg. C

Fort Collins, CO 80526-8118

(970) 226-9398

Or visit the Fort Collins Science Center website at https://www.usgs.gov/centers/fort 


\section{造}

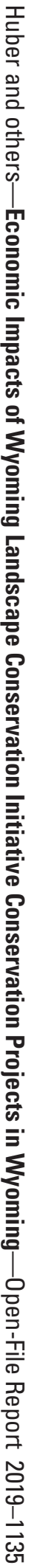

I S B N 978-1-4113-4342-9 